Revue d'Allemagne et des pays de langue allemande

50-2 | 2018

Humanités environnementales - Quoi de neuf du côté des méthodes?

\title{
Arts Awareness for new thinking of body
}

\section{Miki Okubo}

\section{(2) OpenEdition \\ Journals}

Electronic version

URL: https://journals.openedition.org/allemagne/871

DOI: 10.4000 /allemagne.871

ISSN: 2605-7913

Publisher

Société d'études allemandes

\section{Printed version}

Date of publication: 30 December 2018

Number of pages: $267-278$

ISSN: 0035-0974

\section{Electronic reference}

Miki Okubo, "Arts Awareness for new thinking of body", Revue d'Allemagne et des pays de langue allemande [Online], 50-2 | 2018, Online since 30 December 2019, connection on 27 May 2021. URL: http://journals.openedition.org/allemagne/871 ; DOI: https://doi.org/10.4000/allemagne.871 


\section{Arts Awareness for new thinking of body}

\section{- Miki Okubo*}

\section{Introduction}

This article focuses on my experimental practices and research on the possibilities of "arts awareness", through medical and ecological approaches for public understanding of "good health", "hygiene in life" and "sanitation", as well as social/ethical/cultural contributions from artistic activities that have made particular medical methods comprehensible for a public audience.

As a researcher on aesthetics and contemporary art, specializing in the representation of self-image through different modes of expression, I have been strongly interested by the phenomenology of the human body and the contemporary corporeality characterized by our post-modern era, within which we are constantly surrounded by digital technologies, new media devices, as well as a flood of information. In a society of information, our bodies are seriously endangered by the excessive quantity of information about how to maintain a proper care of our own body what is a healthy life, which foods are good for improving our health, what is an ideal lifestyle regarding hygiene and sanitation? I consider the contemporary situation around our corporeality and body consciousness as "being in danger" because of our naivety about given information, and obsessive attention to everything relating to good health. In my observation, we know that an excessive care for the body and obsessional attention given to keeping good health does not always yield a positive effect, but on the contrary can cause negative consequences. In regard to this, I will discuss several social problems observed in contemporary urban life connected to the weakening of our natural physical resistances or capacities for surviving any environmental difficulties. These problems consist of different elements: biological, chemical, ethical, social, and cultural factors. Imagine our daily life in a cell-like flat in Tokyo or in Paris. Attention paid to cleanliness goes beyond the level of sufficiency necessary to keep our body in good health, but rather

* Ph.D on Aesthetics, Sciences and Technologies of Arts, lecturer of University Paris 8, member of Japanese and International Associations of Semiotic Studies as well as those of Aesthetics. 
often goes up to an excessive level of excluding anything seemed as "dirty" according to life standards "made-up" by generalized discourses. Being fastidious about cleanliness, for example, seems to be one of the typical anxious symptoms in our society, in which individuals are highly educated about what entails a supposedly appropriate sanitation in urban life. The excessive use of chemical cleaner materials for domestic purposes also makes us exposed to yet another worrisome situation: it is known that the use of certain chemical cleansers affects our congenital resistance. Certain cosmetics or daily habits based on beauty culture can impact our body negatively: cleansing, making-up with chemical materials, perfuming, depilating or deodorizing to the utmost extent.

Our body consciousness is formed in social contexts, especially based on a kind of idealization of the human body form, supported by aesthetics, beauty culture, and public desires incited by mass media, that all together play an important role in forming the contemporary corporeality as well as the modern modality of living the body. "Body as fragments" or any body parts lit up by the flashlight, is one of symbolic images of many modern medical scenes (remember for example the conventional cinematographic scene of a surgical operation, or medical examination). Beyond our limited ordinary knowledge, advanced medicine and developed technologies applied to medical use easily surpass a pedestrian understanding of the body, commonly creating the cultural phenomena of misunderstanding or miscommunication between specialists (in particular fields such medical care) and ordinary people (patients and their families, or any kin). "E-health", one of eminent medical methods developed thanks to advanced digital technologies, for example, is considered desirable for stocking, classifying, and identifying huge medical data of individuals. It allows us to obtain personalized treatments based on a great deal of personal information (genetic and inherited information, history of illness, particularities of the person's lifestyle, and so on), while we are not always totally satisfied with given treatments because it is inevitable to suffer from a gap between "how feel the body as the subject" and "how the body is dealt with as the object in medical scenes". We will return to tackling this problematic of the body as the subject-object in the following chapters, and I would like simply to note that this gap, which can be due to biological, ethical, cultural or philosophical backgrounds, is the key to unlocking the labyrinth of bien-être in our real life.

Here, I would like to explain why my research focuses on the ecological approaches as well. Thinking of the veritable signification of being healthy means reconsidering the condition of our body in its environment. How does our body establish a relationship with the surrounding environment? Which reactions and interactions are produced with others, other animals, or all living things existing in the environment? In this specific period, thinking of "ecology" is appropriate to our actual society and necessary in order to establish a new theory on a possible relationship between the human body and its environment. When I use the term "ecology", it does not only focus on humans' (or any other living things') reactions with the natural environment, but also different surroundings, including human relationships (family, friends, neighborhoods, communities), artificial environments (clothes, houses, areas, regions, cultures, information, education, etc.). It is time to reconsider and study a new ecology more appropriate to our actual mode of existence on the Planet. And, I believe that in such an interdisciplinary field our unique medical and ecological approaches for "art awareness" can contribute to deepening considerations on this topic. 


\section{Important notions for Applications of Artistic Expressions in Medical and Ecological Cases}

This research focuses on the notion of "hygienic" causing different problems in our daily life, referring to the notion of "pharmakon" (poison = remedy) through considering its etymology and new interpretation in today's social/cultural/ethical context, in order to construct a new phenomenology of the human body more appropriate to our recent condition.

\subsection{Hygieia - Goddess of Hygienic Life and Health}

The term "hygienic" refers to the goddess Hygieia, one of daughters of Asclepius, the god of medicine. In my opinion, her presence can play a role in rethinking the true significance of "good health" and "sanitation" in our daily life, and help advance our society as it faces future risks.

Hygieia is the goddess of healing, cleanliness and sanitation while Panacea, her older sister, is the goddess of Universal remedy. Hygieia is also associated with the prevention of sickness and the continuation of good health. She leads people towards the prevention of illness and helps humans maintain good health, while she also gives advice about what to eat, and how to absolve human suffering from disease, by means of natural remedies instead of invasive medical treatment. Thanks to her supernatural power, she is the goddess of good health, knowing the proper cure appropriate to each individual.

This supernatural power of Hygieia can be associated with the personalized medicine mentioned-above which is estimated to be able to provide medication and treatment appropriate to individuals as well as preventions of illness based on personal genetic information thanks to highly advanced genetic technologies. In this sense, personalized medicine can be considered as method personalized to each of us, referring directly to the particularity of the "physical" (our existence as material). At the same time, thinking of "sanitation" and "hygiene" means learning about the ideal relationship between humans and our surrounding, allowing us to keep our health.

There is one symbolic story referring to Traditional Chinese Medicine (Oriental medicine); doctors are given various forms of appreciation by their patients who keep good health, while they don't receive rewards when their patients fall sick. That is because the doctors' mission is to keep their patients' bodies healthy, and because the prevention from illness is the most important role of medical attention. The fact that a patient falls sick is a grave mistake by his doctor, who is held as the person responsible.

\subsection{Notion: Pharmakon}

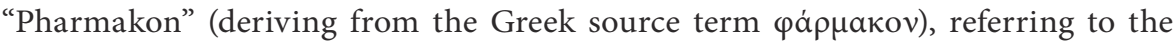
everyday meaning of pharmacology, denotes an interesting notion having a double meaning: remedy and poison. This word is also generally known as triple meaning: remedy, poison and scapegoat referring to the pharmakos ritual of human sacrifice (the Ancient Greeks' rite in which a cripple or criminal was cast out of the community in response to natural disasters as well as calendrical crisis). The first and second meanings are therefore based on materiality, and this term used to be originally employed in a medical sense, since Plato developed this notion as philosophical term as we can read 
in his treatment of writing in Phaedrus. Since then, this term has enjoyed a common application in philosophical considerations: Jacques Derrida, in his Plato's Pharmacy (La dissémination, 1993), defined writing as pharmakon.

In my argument, I employ this term in its first and second meanings - remedy (treatment, drug) = poison (some cosmetic damaging our body, etc.), as well as scapegoat (sacrifice). Then, I examine inappropriate treatments (medications, dosages) carried out before various diseases harbored within the human body. I also aim at finding possible ways to live our bodies based on concrete situations in contemporary society, from examples displaying the healing power we have by nature and our possible commitments to the environment.

\section{Artistic Experimental projects in Medical and Ecological Cases}

\subsection{Project "Live or live better?" ("Vivre ou vivre mieux?")}

Now, I would like to introduce the project "Live or live better?" as one of the most important projects in our research. This work, consisting of Segard's drawings and my text, has been presented several times in Nantes and in Japan such as the Institute of Health Researches in Nantes and CAS (Osaka, Japan). This project focuses on evoking the problematics and issues of public awareness of personalized medicine, and treatments based on this method. Personalized medicine is one of the most advanced medical methods based on individuality in medical treatments, medications, and prevention of diseases. This project highlights what causes difficulties in its application, issues in the patients' comprehension, as well as what is the very psychical/physical experience undergone through this medical method.

\section{Personalized Medicine: Live or Live Better?}

In the project "Live, or live better?", Segard interrogates modalities of our daily life. What interests us here apropos personalized medicine, is in particular its utilities and possible practical implementations, and his mention of Hygieia, a goddess of hygienic and good health, who is a daughter of Asclepius, god of medicine in ancient Greek mythology.

Personalized medicine generally considered as "tailored medicine", often expressed in analogy of fashion, like tailor-made costume or shoes, appears to advertise something like this: "the medical method is something tailor-made, proposing medications, treatments, and therapies perfectly appropriate to your body, then leading you to ameliorate your physical condition!" Despite this favorable image, it is still not obvious for us to engage in collective application of this new method. Needless to say, we can "feel" how costumes and shoes suit well to our body when putting them on, while that is not the case of personalized medicine. It is impossible to feel any real/ concrete sensation or its effects of medication or treatment, even if we were to simply acquiesce that there are some medical results like reduction of pain, healing thanks to treatment, numerical improvement in blood test, and so on. The results given are likely due to numerical/informational observation, that is, "objective" data. The most interesting topic for me in this regard is the incomprehensible nature of our own body to ourselves, of the impossibility to seize our flesh in its structural sense. 


\section{Impossible to Seize: Absolute Obscurity - the Body}

Without enough knowledge about our own bodies, we are not capable of proposing good things based on scientific reasons to our doctor. In the Japanese language, the term “patient” is written in kanji (Chinese characters), 患者, kanja, and means exactly this typical situation of the patient. The second letter 者 means a person, while the first 患 represents an existence of suffering, and can be further decomposed into two radical parts: 串, an object penetrating something and 心, the heart. A patient 患者 is for me clearly represented as an anxious person because of the shortage of knowledge and information on his body.

Concerning this point, medicine as a research field has always been highly specialized and pointed. The patient cannot understand his own physical status very well, even though the body suffering from disease belongs to this person. One of reasons for this obscureness derives from the characteristic ontology of the human body: both being an object and a subject, having its outside and inside. Imagine that one part of our body doesn't work correctly, then the part is examined, diagnosed and treated; this "initially integrated" body becomes decomposed, broken up, and fragmented to the extent where we cannot identify our own body. What we experiment with in medical scenarios as patients, is often a kind of persuasion, beyond the obscureness of human body, saying that we have to believe your doctor, science, and medical knowledge because it is those who know much more than us about our body. This mental control allows patients to accept suggested treatments and medications, and even follow difficult and painful treatments. In the history of science, there has always existed a crucial gap between doctor and patient apropos of knowledge of body in illness.

The technical basis of this method derives from DNA analysis, in which each individual is scanned, digitized, interpreted, and regarded as objective information. It is important to underline that this genetic information is a set of confidential codes taken as architectural plan of each individual, even if the individual himself doesn't have ways to decrypt it.

The operations in medicine that depend on what is knowable or not knowable is why the achievement of Human Genome Project was very significant. Conceived in the 1980s, the project attempting the complete identification and mapping of Human DNA sequences started in 1989 in the USA. Due to a number of laboratories collaborating (or rivaling), the project achieved successful completion in 2003. The complete version published three years later ensured us that $99 \%$ of DNA sequences had been decoded with $99 \%$ of precision. Since 2016, the DNA sequencing has been stocked in a database on the Internet, as a free resource for those who like to consult it. The field of bioinformatics has progressively developed, becoming a basic resource for personalized medicine. In the coming years, one can anticipate that many more research projects, experimentations, and applications will emerge in relation with informatics and sciences.

In brief, the achievement of Human Genome Project and DNA sequencing impacted our fundamental comprehension of our existence because this achievement, especially almost perfect DNA sequencing, means a loss of mystery in the inner workings of the human being, which could be a landmark somehow (as a kind of hope), enabling us to distinguish human beings of artifacts. Disappointed or delighted, we realize that this hunger for absolute scientific knowledge about our body reflects to us our imitation as a sort of "God." 


\section{Charcoal: Anonymous Nature, Identity and Confidentiality}

As we can see in the drawings, in the performance, Jérémy Segard appears with a blackened face. What he puts on the face is charcoal, a symbolic material for drawing. For starting the act, Segard embodies a character. This approach and his appearance reminds us of The Angel (1992), a work of Michaël Borremans, a Belgian artist, because blackness of the face resembles the angel, and makes his persona seem like a mysterious, strange, and anonymous creature. One anonymous man in a white costume (suggesting a medical scene) stays in silence. At first sight, we might pose an absurd question, but nevertheless essential: this man, is he a doctor or a patient?

Remember the situation in a medical situation where our body is exposed. It is not desirable to be ashamed of personal information insensitively revealed in any medical situation. As mentioned by Paul Virilio in his term "dromology" (1) meaning the logic of speed characterizing our technological society or, as defined by Marc Augé, the expression "non-lieu" (2), in our contemporary society we are often thrown into a white space, empty and anonymous, in the form of huge stations, control in the airport, etc., in which people move at great speed. Regarding the medical scene, this deprivation of identity is paradoxically associated with an indispensable unveiling of confidential information. At the emergency room, a working person promptly puts a bracelet on one of our wrists, and we are suggested to play a role of "patient". Because of the anonymous status of human bodies, there can be mistakes due to the error of patient identification, or error of treatments and medications given to an individual, the false exchange of babies, etc.

Although we live in an individualistic society, our individual bodies cannot help but be reduced to being universalized bodies in general in medical contexts. In medicine, we are then liberated from any identifying information: origin, family, studies, career, salary, etc. We turn into simple flesh to be examined, treated and cared; our body is a material object.

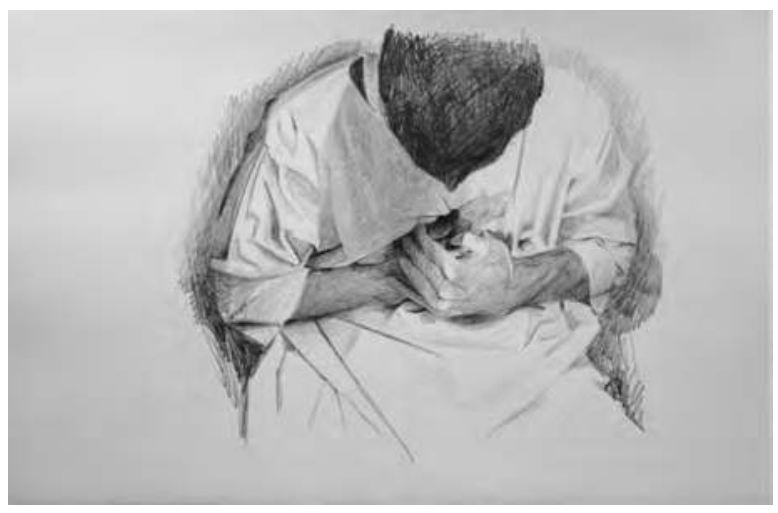

Jérémy Segard, Vivre ou vivre mieux?, 2014

1 The dromological society or "dromospère" is a key notion of Paul Virilio's theory about today's urban life characterized by technology and velocity.

2 In his book No places: introduction to an anthropology of supermodernity (1995), Marc Augé defined a "no place" as an interchangeable space where the individual keeps anonymous. 


\section{Important Influences by Joseph Beuys: How can Art be "socially significant"?}

For better understanding of Jérémy Segard's action, we can briefly take a look at some materials used in his performance. His concern in particular elements, as well as art practice for a social purpose should remind us of Joseph Beuys' work as well as Garman social arts' inspiration of the 1960s, especially his curiosity for specific materials and concept of "social sculpture" (3). Beuys, after having experienced a plane accident in 1964, started to work with different materials such as felt, grease, honey, and soil. Introducing these new materials in his creation was absolutely necessary for Beuys, for whom art impacts real life and acts concretely on important social problems. Using these materials and quoting his social sculptural concept signifies the realization of a social body, associating an individual to the society, organically through art. When Segard takes soil, eggs, wood, carbon, or cotton in his hands, the choice of these elements is unique, for he establishes a precise matter of concern in a social context, through his artistic expression.

\subsection{Exhibition "Pharmakon: Medical and Ecological Approaches for Artistic Awareness"}

To clarify the points I developped above, I would like to show some analysis of artworks I have presented in another experimental practice in the form of an exhibition, focuses on "hygiene" as a notion that is becoming problematic in our daily lives. We explore the etymology of "pharmakon" (poison = remedy) and propose a fresh take on this concept in today's social/cultural/ethical context, in order to construct a new phenomenology of the human body more appropriate to our modern (post-modern? Or advanced modern condition?) condition.

The exhibition "Pharmakon: medical and ecological approaches to artistic awareness" took place in Kyoto (The Terminal Kyoto, Kyoto, Japan) and Osaka (CAS, Osaka, Japan), subsidized by Pola Foundation for Art and the Asahi Journal Foundation from $1^{\text {st }}$ December to 23th December 2017. As a curator of this exhibition, I presented nine artistes; five French artists: Jérémy Segard, Florian Gadenne, Anne-Sophie Yacono, Evor and Akira Inumaru (Japanese artist working in Paris and Rouan, France), as well as three Japanese artists: Tomohito Ishii, Sonomi Hori, and Miho Tanaka. Miki Okubo, the organizer and curator, also presented works in the exhibition.

3 In Joseph Beuys. Is it about a bicycle?, Beuys explains about material use - fat, copper, and felt in his objects and actions: "[...] The fat was for example for me a great discovery because it was a material which could appear as very chaotic and undetermined into a movement for finish in a geometric context. I also had three fields of power and, then, one idea of the sculpture. It was the power in a chaotic condition, in a condition of movement and form. And these three elements, form, movement and chaos were undetermined energies from which is derived my theory of the sculpture and the human psychology as power of thinking and sensibility; and I found that it was at this point where the adequate schema for understanding all social problems. It also involved organically the issue of social body, of individual humanity, of the sculpture and the art themselves. I needed the way of expression. I had already fat. In addition, I needed a quick element, material carrying electricity, it was the copper. And then I needed other things for isolating such sectors from others and I used therefore felt. Hence, we can say that it was the first concept of energy... but it is also a sort of anthropology!" (Bernard Lamarche-VAdel, Joseph Beuys. Is it about a bicycle?, Paris, Éditions Marval/Galerie Beaubourg/ Sarenco-Strazzer, 1985). 
The exhibition enables us to tackle the following questions: What are the possible relationships between human activity and human surroundings? What do advanced medical techniques and new technologies mean for human beings who are nothing but another part of nature? These questions are confronted in various ways by the exhibition's artists, each offering their own unique artistic approach.

Since the average person doesn't possess the technical knowledge necessary to understand what happens in specialized scientific research around advanced medical treatments, decision-making when facing delicate medical situations can be burdensome. Despite this comprehension gap, "medical" and "ecological” issues deeply affect our individual lives, and are commonplace topics familiar to most. Facilitating communication by linking exhibition visitors or ordinary people with research, doctors, scientists, or any other experts, can help nourish a better understanding of these complex fields that affect human lives so deeply. Creating a basis for this communication to take place will open the door to transdisciplinary research and practices. I consider my challenge to be of an investigative nature, to seek out and encourage dynamic dialogue between artistic and scientific fields, and aesthetic experience, in order to achieve a more global artistic awareness.

The shape of a voluminous tower: cellule babélienne ("Babelian cell"), is constituted by different organelles of eukaryotic cells - nuclear, Golgi apparatus, endoplasmic reticulum and ribosomes, mitochondria, and other structures. The tower shape also refers to a pyramid (or other mountainous tombs) or to Laputa; Castle in the Sky, a film realized by Hayao Miyazaki. An island in the sky, called "Laputa" in the film, is inspired at first by one description appeared in the third chapter of Gulliver's Travels by Jonathan Swift, based on an untraceable text about heaven written by Plato.

The tower constituted by different organelles aims at the heaven. It has a central part: the nucleus. Visibly and invisibly, this evolving volume is a veritable host of all element-organelles that blend together with each other, mute, and degenerate. Babel

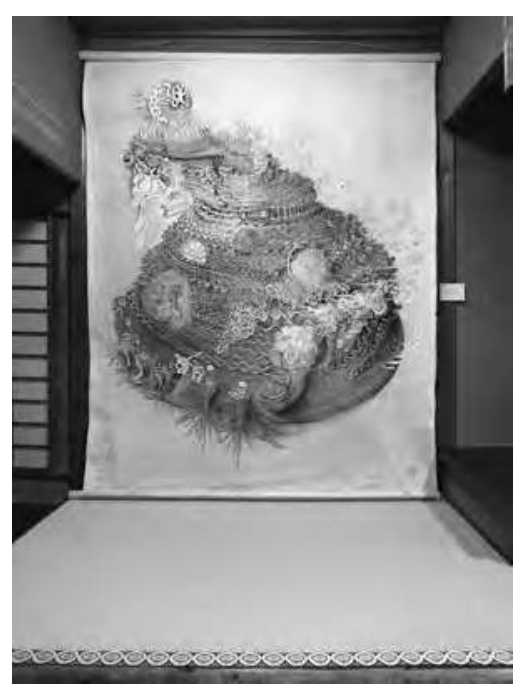

Florian Gadenne, cellule babélienne, 2016
Tower is a metaphor of man's hubristic pride, deluding himself into belief about his potentiality up to eternity: God. Even after being dispersed by linguistic incomprehensibility, the human is still proud of himself for the certainty of his science, mathematics, physics, and cosmology. The worst thing the human has understood due to his tenacious searching about biological modalities is the universality of organelle composition in every eukaryotic cell. It reveals, then, the genetic information as a homogeneous substance common to all terrestrial creatures. Humankind reaches not only impossibility of communication as a result of linguistic division, but also a sort of naïve and obsolete belief in hierarchical thought of an ecological pyramid, whereby homo sapiens is positioned at the top... This creed is naive and obsolete, because he knows now that at 
the level of genetic information he is practically the same as other vertebral animals, and the composition of organelles is identical within any eukaryotic cells. The Tower of Babel: does it still mean a symbolic impossibility?

Babel Tower is a symbol of human pride to reach heaven. This proud self-consciousness is associated with the absolute superiority of human beings to any other creatures on the planet. Gadenne's drawing, consisted of organelles of both of animal and vegetal cells, proposes a different perspective concerning the ecological pyramid. The human being is not the only species which reigns above the whole planet, but just an animal composed by eukaryotic cells, just as other species. He interprets God's intervention by destroying the tower as God's guidance to bring human beings closer to understanding a harmonious ecology, or how to coexist with other living things instead of ruling them, polluting the Earth, or considering himself as an existence similar to God. In my sense, the point that cancels the hierarchy among creatures, in order to found a better ecology, is extremely important.
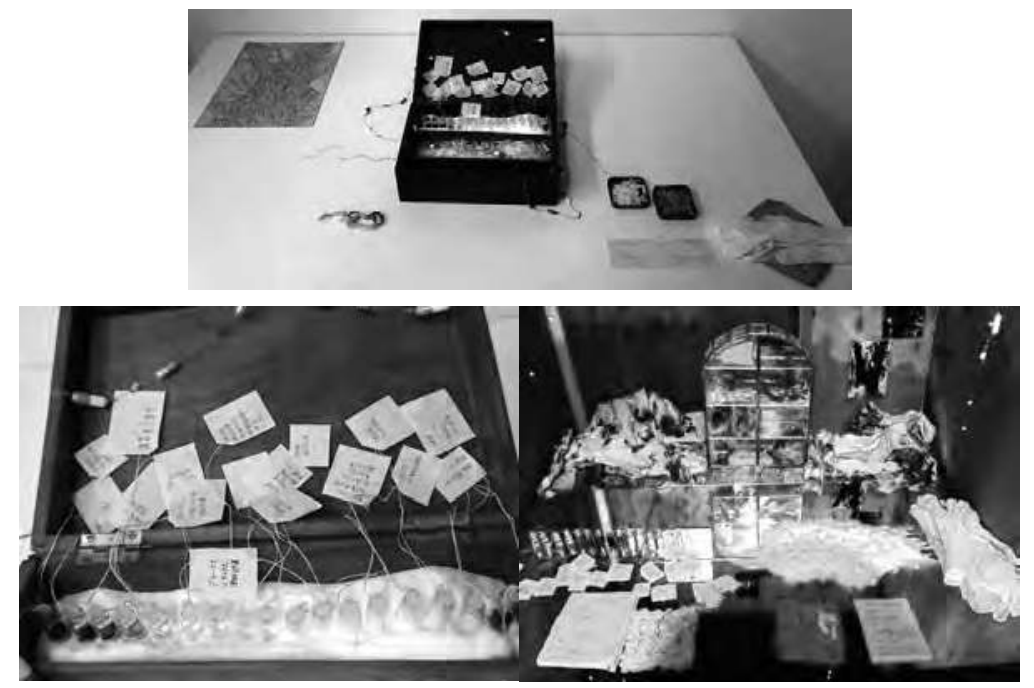

Miki Okubo, Placebo Candidates, Undesirable Effects, 2017

Her work, Undesirable Effects, is a type of participative work whereby people are invited to write one undesirable effect of medicine on a tiny piece of paper, after which they put it inside of an empty capsule. Taking medicine is a familiar act when being in ill, and we habitually take some pills before or after meals. Some medicines demand a medical prescription, and others available over the counter. If you take a look at their instruction manual, you must be surprised at the list of a number of possible secondary effects (side effects), which are unwanted. These effects can range from relatively common effects such as sleepiness, nausea, upset stomach, and itching, to graver consequences like allergic reactions and any other strong impact causing the death. We see any potential symptoms on the instruction manual with statistic information such as probability. Could we still feel reassured of the medicine's safety, even if the effects are very rare? The way of defining "side effect" of course depends on what we look for. 
We like to think drugs are designed for exact purposes, however, many of them are not initially targeted in the way that we may hope. As a famous example, sildenafil, sold as the brand name Viagra, is a medication used to treat erectile dysfunction and pulmonary arterial hypertension. It was Pfizer, a drug company, that was looking for something for relaxing blood vessels. When Pfizer was about to abandon further trials, thanks to trial volunteers' witness, scientists discovered an unusual side effect - lots of erections. Among medications we benefit today, many of them used to be discovered for completely different purposes. We don't always know what the medicine can cause when we take it into our body, and there is too long of a list to know all potential effects noticed in the instruction manual. This installation shows a mountain of capsules enveloping unwanted effects, written on minuscule paper, an artwork that brings us to reconsider what we absorb in our body.

Placebo Candidates is also installation work consisting of a small bottle filled with different "placebo candidates," white and colored powder, unknown liquid, and minute grains. They are substances that she proposes as potential placebos. The placebo effect refers to some psychological phenomenon in which the recipient perceives an improvement in condition due to personal expectations, rather than the treatment itself. A placebo, derived from Latin origin, means "I shall please," and it is therefore a substance or treatment with no active therapeutic effect. In medical research, placebos have played important methodological roles, because instead of giving patients any substance which potentially provoke unwanted effects or more or less weary their body, placebo usage can be hopeful for improving a physical state without giving any damages. The concept of this work reminds us of the importance of our natural physical resistance and the force of positive beliefs. Thinking has an important role in changing our body condition; the placebo effect proves perception and the brain's role in physical health.

\section{Conclusion: Living or Living Better?}

Our body is a recipient, a tube, that is a great "hole" through which materials pass, in which they are absorbed and assimilated. Indeed, the recipient possesses two aspects: inside and outside. Its inside wraps contents, its outside protects what is inside. The human body therefore shares this principle: the outside (membrane, skin, muscle, hair, etc.) protects his inside (blood, bodily liquid, organs, guts, blood vessels, brain, etc.). The inside more or less "visible" in the case of a pot is naturally "invisible" in the case of a human body. We cannot visually know exactly what is inside (its colors, textures), and nor how our body work in concrete ways. All things happening in medical rooms are a disruption of this common meaning apropos of the inside-outside of body. A chirurgical intervention can make us discover our bloody inside, which should seem to us be "impressive." When we look at a piece of an excised organ, or when our doctor let us see a radiographic or echographic images, we are upset by the "unknown" visual of our own body.

If advanced medical methods such as personalized medicine gives us anxiousness in spite of hope, as well as extraordinary advantage, it is because this new apparatus can turn our body into "a foreign body", which is controllable, yet intangible, far from our actual physical existence. One day, when precise measurement technologies prevent us 
from getting any potential diseases because personal DNA analyses will be perfectly implemented, all of us will survive until the end of our possible lifetime unless we are not killed in an accident. At that time, everyone must search to live a happy life, not just a long life forced into longevity by advanced technologies, nor obligated to live a stable life given by developed medicine, but we have to live better, that is, live happy from our own will, our own desire, in order to benefit and appreciate the pleasure of life. Indeed, thinking about all questions treated above can help us to direct toward a good path bringing us to a happy life.

\title{
Bibliography
}

Jacques Derrida, La dissémination, Paris, Seuil, 1972.

Lucien Sfez, La santé parfaite - Critique d'une nouvelle utopie, Paris, Seuil, 1995.

Bernard Stiegler, Pharmakon, pharmacologie, Ars Industrialis, http://arsindustrialis.org.

Augustin BerQue, Le sauvage et l'artifice. Les Japonais devant la nature, Paris, Gallimard, 1986.

Catalogues

Miki Окиво et Jérémy SEgARd, Vivre ou vivre mieux?, Lotokoro, 2014.

La toilette - Naissance de l'intime, Musée Marmottan Monet, Éditions Hazan, 2015.

L'UN L'AUTRE, Lotokoro, 2016.

\begin{abstract}
This article focuses on my experimental practices and research on the possibilities of "arts awareness", through medical and ecological approaches for public understanding of "good health", "hygiene in life" and "sanitation", as well as social/ethical/cultural contributions from artistic activities that have made particular medical methods comprehensible for a public audience. At first, I present the points I consider as alarming situations, observed in today's social life, and then explain which phenomena or people's practices are worrisome. To develop my argument, I will then introduce two key notions in my theoretical and practical research: the notion of "hygiene" and "pharmakon".

Different examples of aesthetic experimentation will be introduced. The first one: "live or live better" ("Vivre ou vivre mieux?") is a project conceived by Jérémy Segard, a French artist who collaborates with different health institutions in Nantes, France, whose artwork concept is deeply influenced by Joseph Beuys. I participated in this project as a writer for thinking of the signification of the personalized medicine as well as its problematic in practical applications. The second project bears the very title "Pharmakon"; it is an exhibition curated by myself, that took place during the same period in December 2017 in Kyoto and Osaka. In introducing concepts from these experimental practices, I analyze how these realized projects belong in academic, artistic, and practical contexts.

It is time to reconsider and study a new ecology more appropriate to our actual mode of existence on the Planet. And, I believe that in such an interdisciplinary field our unique medical and ecological approaches for "art awareness" can contribute to deepening considerations on this topic.
\end{abstract}




\section{Résumé}

Cet article met en lumière mes pratiques et mes recherches expérimentales sur les différentes formes de "sensibilisation artistique", à travers des approches médicales et écologiques ayant pour but une compréhension générale de la notion de "bonne santé", d' "hygiène de vie » et de "soins", ainsi que des contributions sociales/éthiques/culturelles des activités artistiques liées aux domaines particuliers tels que la médecine et l'écologie. Je mentionnerai tout d'abord certains phénomènes observés dans notre société, considérés comme inquiétants. Afin de développer mon argument, j'introduirai deux notions clés dans mes recherches théoriques et pratiques: "hygiène» et "pharmakon".

Différentes expérimentations esthétiques seront introduites. La première: "Vivre ou vivre mieux?" est un projet conçu par Jérémy Segard, artiste français collaborant avec différentes institutions de la santé à Nantes; son travail artistique est profondément influencé par Joseph Beuys. Ma participation à ce projet comme auteur était de réfléchir à la signification de la médecine personnalisée ainsi qu'aux problématiques liées à son application pratique. La seconde expérimentation intitulée "pharmakon" est une exposition que j'ai organisée à Kyoto et Osaka en décembre 2017. En introduisant ces concepts et ces pratiques, j'énonce comment ces projets se sont réalisés académiquement, artistiquement et socialement.

Il est temps de reconsidérer et de fonder une nouvelle écologie plus appropriée à notre mode d'existence au sein de la société et de l'environnement actuels. Je crois en une possible contribution des approches interdisciplinaires que sont la médecine et l'écologie pour une "sensibilisation artistique» ainsi qu'une meilleure compréhension publique sur le sujet. 